\title{
Democracies and International Relations
}

\author{
Dingyu Chung \\ Utica, Michigan, USA \\ Email: dy_chung@yahoo.com
}

How to cite this paper: Chung, D. (2019) Democracies and International Relation. Open Journal of Social Sciences, 7, 249-271. https://doi.org/10.4236/jss.2019.77023

Received: June 21, 2019

Accepted: July 23, 2019

Published: July 26, 2019

Copyright $\odot 2019$ by author(s) and Scientific Research Publishing Inc. This work is licensed under the Creative Commons Attribution International License (CC BY 4.0).

http://creativecommons.org/licenses/by/4.0/

\begin{abstract}
This paper proposes the five different democracies and their international relations. Democracy literally means that power (kratos) belongs to the common people (demos) instead of dictators and inherited kings-aristocrats. Different types of powers and different types of the common people constitute different types of democracies. Within a democratic nation, the intergroup relation among different social groups can be competitive or cooperative. The most conventional democracy is liberal democracy where power, intergroup relation, and people are liberty, competition, and all people, respectively. The power of the liberty to compete belongs to all people. All people have liberty to compete. Democracies in general are the combinations of different powers (elitism, tradition, liberty, equality, and wellbeing), different intergroup relations (competition and cooperation), and different people (few, most, and all). Therefore, depending on powers, intergroup relations, and people, the five democracies are elite democracy (elitism, competition, few people), nationalist democracy (tradition, competition, most people), liberal democracy (liberty, competition, all people), socialist democracy (equality, competition, all people), and relationalist democracy (wellbeing, cooperation, all people). Different people in different times, cultures, and political situations have different democracies. Each democracy has advantages and deficiencies. The democracies today are mostly mixed democracies to minimize deficiencies. The optimal mixed democracies have competition, cooperation, tradition, liberty, equality, and wellbeing. International relations as international intergroup relations reflect democracies as domestic intergroup politics. Liberal, socialist, and relationalist democracies are for all people, so they can generate cooperative international orders (liberal, socialist, and relationalist) for all nations within their respective democracies. For example, liberal democracy can generate cooperative liberal international order for all liberal democratic nations. Elite democracy and nationalist democracy are not for all people, and are against foreigners, so they can only generate competitive international relation as competitive realism. Peace and prosperity in the world can be maintained by proper international relations.
\end{abstract}




\section{Keywords}

Democracy, International Relation, Nationalist Democracy, Liberal

Democracy, Socialist Democracy, Relationalist Democracy, Competitive

Democracy, Cooperative Democracy, Realism, International Orders

\section{Introduction}

This paper proposes the five different democracies and their international relations. Derived from the ancient Greek "demokratia", democracy literally means that power (kratos) belongs to the common people (demos). In democracy, power belongs to the common people instead of dictators, inherited kings-queens, and inherited aristocrats. Different types of powers and different types of the common people constitute different types of democracies. A nation consists of many religious groups, ethnic groups, classes, and geographic groups etc. Within a democratic nation, the intergroup relation among different social groups can be competitive or cooperative [1]. The most conventional democracy is liberal democracy where power, intergroup relation, and people are liberty, competition, and all people, respectively. In liberal democracy, the power of the liberty to compete belongs to all people. All people have liberty to compete. Democracies in general are the combinations of different powers (elitism, tradition, liberty, equality, and wellbeing), different intergroup relations (competitive and cooperative), and different people (few, most, and all). Therefore, depending on powers, intergroup relations, and people, the five democracies are elite democracy (elitism, competition, few people), nationalist democracy (tradition, competition, most people), liberal democracy (liberty, competition, all people), socialist democracy (equality, competition, all people), and relationalist democracy (wellbeing, cooperation, all people). Different people in different times, cultures, and political situations have different democracies. Liberal democracy is just one of these democracies.

In terms of culture, the competitive democracies originated from the West include elite democracy, nationalist democracy, liberal democracy, and socialist democracy, and competitive intergroup relation dominates cooperative intergroup relation in terms of partisan competition. In competitive democracies, real and imaginary political opposition groups always exist against the ruling government as described by Joseph Schumpeter [2]. The cooperative democracy includes relationalist democracy originated from the East, and cooperative intergroup relation dominates competitive intergroup relation. In relationalist democracy, government and people cooperate together for the wellbeing of people. New and opposite ideas are incorporated cooperatively by continuous reform and opening without the need of opposition groups. Each democracy has advantages and deficiencies. The democracies today are mostly mixed democracies to minimize deficiencies. The optimal mixed democracies have competition, 
cooperation, tradition, liberty, equality, and wellbeing.

International relations as international intergroup relations reflect democracies as domestic intergroup politics. Liberal, socialist, and relationalist democracies are for all people, so they can generate cooperative international orders (liberal, socialist, and relationalist) for all nations within their respective democracies [3]. For example, liberal democracy can generate cooperative liberal international order for all liberal democratic nations. Elite democracy and nationalist democracy are not for all people, and are against foreigners, so they can only generate competitive international relation as competitive realism [4]. Peace and prosperity in the world can be maintained by proper international relations. The five democracies are described in Table 1.

Section 2 describes democracies in terms of the maximum participation rates of people in government, intergroup relations, the powers of democracies, the rules and accountabilities of democracies, and democratic systems. Section 3 deals with international relations in terms of realisms, liberal international order, socialist international order, relationalist international order, and mixed international order.

\section{Democracies}

Democracy literally means that power (kratos) belongs to the common people (demos). In this paper, democracies are derived from the three components consisting of the maximum participation rates (few, most, and all) of people in government, the intergroup relations (competitive and cooperative intergroup relations), and powers (elitism, tradition, liberty, equality, and wellbeing). Derived from the three components, the five democracies are elite democracy, nationalist democracy, liberal democracy, socialist democracy, and relationalist democracy.

\subsection{The Maximum Participation Rates of People in Government}

In terms of the maximum participation rate of people in government, elite democracy such as in ancient Athens and early America is for few elite people who had adequate education and living standard to participate in government. The discrimination against women, poor people, and minorities were acceptable. Nationalist democracy is for most people who are in majority and believe in tradition. The discrimination against non-traditional people and minorities are acceptable. Liberal democracy is for the liberty of all people. Socialist democracy is for the equality of all people. Relationalist democracy is for the wellbeing of all people.

Historically, civilization was an irreversible process, because the social group of large population established by civilization had to be supported by agriculture. The reverse to the pre-agricultural-nomadic (pre-civilized) society would have led to mass starvation. The agricultural society required to stay in the same place, so it was more prone to the periodic local natural disaster, unlike the 
Table 1. The five types of democracy.

\begin{tabular}{lllll}
\hline democracy & power & \multicolumn{2}{l}{ intergroup relation for } & international relation \\
\hline elite democracy & elitism & competitive & few people & realism \\
nationalist democracy & tradition & competitive & most people & realism \\
liberal democracy & liberty & competitive & all people & liberal international order \\
socialist democracy & equality & competitive & all people & socialist international order \\
$\begin{array}{l}\text { relationalist } \\
\text { democracy }\end{array}$ & wellbeing & cooperative & all people & $\begin{array}{l}\text { relationalist international } \\
\text { order }\end{array}$ \\
\hline
\end{tabular}

hunter-gatherer society that was free to move away from local natural disaster. The constant population pressure and the periodic natural and man-made disasters caused the deficient resource and security. The hunter-gatherers were averaged 6 inches taller than agricultural peoples until industrialization. Today, we are now as tall as we once were. The life expectancy in the agricultural-nomadic society was actually shorter than in the hunter-gatherer society.

The rigid agricultural social-economic structure under chronic natural and man-made disasters could not provide adequate education and living standard to most people, so most people were poor in education and living standard. Without adequate education and living standard in the highly hierarchical agricultural society, most women, working people, and minorities were dominated by few educated and wealthy elite people, and were powerless and marginalized in the political participation. As a result, in elite democracy under the agricultural society as in ancient Athens and the early United States of America, the political power belongs to few elite people who had adequate education and living standard to meaningfully participate in the politics forming viable government. Even though some idealistic thinkers wanted to have all people participating equally in government, the realistic democracy was still elite democracy whose maximum participation rate of people in government was low. In elite democracy, the discrimination against women, poor working people, and minorities who did not have political power was acceptable.

After the Industrial Revolution, the productive and efficient industrial social-economic structure under chronic natural and man-made disasters still can provide adequate education and living standard to most people, so most people are adequate in education and living standard. With adequate education and living standard in the industrial society, women, working people, and minorities are powerful and valued in politics. The democracies become bottom-up democracies for most or all people with the high maximum participation rate of people in government. Women in America started to vote in 1919 many years after the Industrial Revolution in America.

Nationalist democracy is for most people who are in majority and live in accordance to tradition. The discrimination against non-traditional people and minorities are acceptable. Liberal democracy is for the liberty of all people without discrimination. Socialist democracy is for the equality of all people without 
discrimination. Relationalist democracy is for the wellbeing of all people without discrimination.

\subsection{Intergroup Relations}

A nation consists of many religious groups, ethnic groups, classes, and geographic groups etc. Intergroup relations among different groups are based on ingroup and outgroup. In ingroup, individuals have similar interests and outlooks, and produce the feeling of connection among them [5]. Individuals in outgroup outside the boundary of one's own group are different in interests and outlook, and produce the feeling of zero-sum competition toward outgroup. The proper behavior as morality toward ingroup is cooperation, whereas the proper behavior toward outgroup is zero-sum competition [6]. Such ingroup-outgroup boundary instinct appears even in infants at few months old [7]. Intergroup relations include territorial relation for ingroup-outgroup intergroup with a clear boundary between ingroup and outgroup, competitive relation for outgroup-like intergroup without a clear boundary between ingroup and outgroup, and cooperative relation for ingroup-like intergroup without a clear boundary between ingroup and outgroup as shown in Table 2.

A nation consists of many religious groups, ethnic groups, classes, and geographic groups etc. Within a nation, the boundary among these groups is not clear. As a result, without clear boundary, the intergroup relations among different groups within a nation can be competitive or cooperative.

Historically, in the West originated from Greece and Middle East, competitive intergroup relation dominated cooperative intergroup relation, and in In the East originated from India and China, cooperative intergroup relation dominated competitive intergroup relation [1]. Instinctive intergroup relation affects social interaction and perceptions. In relational sociology [8], substantivalism considers individuals as self-subsistent entities capable of social interaction, while relationalism considers the social human practices and the individual's transactional contexts and reciprocal relations. Substantivalism corresponds to competitive intergroup relation where individuals stand alone to compete against one another, while relationalism corresponds to cooperative intergroup relation where cooperative individuals are related to one another. In terms of perception, substantivalism and competitive intergroup relation percept an object as identity standing alone, relationalism and cooperative intergroup relation percept an object to have relation with another object. As a result, the Westerners with competitive intergroup relation pay attention to the focal object separated from its surrounding based on discrete perception, while the Easterners with cooperative intergroup relation attend more broadly to the overall surroundings and to the relations between the object and the field [9] [10]. One typical way to identify the East vs. the West is to pair panda, monkey, and banana. Typically, the Westerners pair panda and monkey for the same category (animals), while the Easterners pair monkey and banana for the relationship (monkey eats banana). 
Table 2. Intergroup relations.

\begin{tabular}{ccc}
\hline Intergroup Relation & Boundary & Intergroup \\
\hline territorial & clear & ingroup-outgroup intergroup \\
competitive & unclear & outgroup-like intergroup \\
cooperative & unclear & ingroup-like intergroup \\
\hline
\end{tabular}

According to psychologists Igor Grossmann and Ethan Kross, Russians located in between the East and the West focus in relationship [11]. Russians tend to be more communal, more focused on interpersonal harmony, and this allows them to see their own personal needs in larger context, from an outsider perspective. Americans, by contrast, tend to focus on the personal. With less of a community perspective, they immerse themselves in the emotional details of negative events, and this self-focus leads to distress and depression. Americans behave as the Westerners, while Russians behave as the Easterners.

Since the West culturally favors competitive intergroup relation, the West has competitive democracy. In the Joseph Schumpeter's competitive model of democracy [2], democracy in the West is a competitive democracy to settle who will govern through a competitive struggle for the people's vote. On this view, democracy does not aspire to represent the will of the people, but just to use political competition to settle the question of who is in charge. The political competition requires partisanship through which large numbers can best be mobilized to participate in politics. As a result, Schumpeterian democracy depends on alternation between two strong parties in government. The party that wins the election exercises a temporary power monopoly, but the loyal opposition as a government-in-waiting whose leaders hope to take power at the next election to continually challenge its policies [12]. The competitive democracies in the West include elite democracy, nationalist democracy, liberal democracy, and socialist democracy. In competitive democracies, real and imaginary political opposition groups always exist against the ruling government.

Since the East culturally favors cooperative intergroup relation, the East should have cooperative democracy. However, the current world is dominated by the economically strong West, so the East has mostly competitive democracies. Few countries such as China, Russia, and Singapore have cooperative democracy which is relationalist democracy based on wellbeing for all people without discrimination. In relationalist democracy, cooperative intergroup relation dominates competitive intergroup relation. In relationalist democracy, government and people cooperate together for the wellbeing of people. New and opposite ideas are incorporated cooperatively by continuous reform and opening without the need of opposition groups. The presence of the opposition is not a requirement for democracy where power belongs to the people with or without opposing political parties. The goal of relationalist democracy is the wellbeing of all people. 


\subsection{The Powers of Democracies}

The powers of democracies belong to people, and are implemented by state. The powers include elitism, tradition, liberty, equality, and wellbeing which are implemented by the states of elite democracy, nationalist democracy, liberal democracy, socialist democracy, and relationalist democracy, respectively. According to Francis Fukuyama [13] [14], political order of liberal democracy consists of three components: the state, the rule of law, and the accountability of election. A successful liberal democracy combines the three components in perfect balance. State as central authority to implement the power of democracy is strong, but it is bound by a transparent system of rule of law and accountability of election to the will of the people. Different democracies have different states, rules, and accountabilities.

Democracies include competitive democracies and cooperative democracy. The basic assumption of competitive democracy is that human nature is instinctively selfish and competitive. The formation of a viable democratic government requires the thinking brain to transform instinctive and disorderly competition into deliberate and orderly competition [15]. As a result, viable democracies must be rationally rule-based and empirically accountability-based. For competitive democracies, the rational rule is the rule of law for all people or the rule by law for selected people, and the empirical (verified) accountability is the accountability of election for all people or the accountability by election for selected people. Therefore, each democracy has power implemented by the state, the rule, and the accountability.

The basic assumption of cooperative democracy is that human nature is instinctively relational and cooperative. All individuals are related to one another in the community of common destiny that produces wellbeing as the state of being comfortable, healthy, secure, and happy. The power of wellbeing from cooperation belongs to all people. The formation of a viable democratic government requires the thinking brain to transform instinctive and disorderly cooperation into deliberate and orderly cooperation. As a result, viable democracy must be rationally rule-based and empirically accountability-based. For cooperative democracy, the rational rule is the rule of relation that dominates the rule of law, and the empirical (verified) accountability is the accountability of professional qualification that dominates the accountability of election. Cooperative democracy is relationalist democracy. The power, rule, and accountability in relationalist democracy as in China, Russia, and Singapore are wellbeing, the rule of relation, and the accountability of professional qualification.

\subsection{Democratic Systems}

Democratic systems include elite democracy, nationalist democracy, liberal democracy, socialist democracy, relationalist democracy, and mixed democracy. Democracies are derived from the maximum participation rates (few, most, and all) of people in government, intergroup relations (competitive and cooperative) 
within a country, the powers (elitism, tradition, liberty, equality, and wellbeing), the rules (the rule by/of law and the rule of relation), and the accountabilities (the accountability by/of election and the accountability of professional qualification).

\subsubsection{Elite Democracy}

Elite democracy is a competitive democracy based on elitism, the rule by law, and the accountability by election for few people. In elite democracy, the power of elitism to compete in government belongs to few people. Few elite people can compete in government belongs to few people. The earliest democracy is elite democracy for few elite people who were adequate in education and living standard. In $508 \mathrm{BC}$, Athenians established the first democracy as elite democracy which involved $10 \%-20 \%$ of the polis population with about 3000 active participants who had the ability to vote competitively. Of this group, perhaps about 100 wealthiest and most influential elite people dominated the political arena. The discrimination against women, poor working people, and minorities who did not have political power was acceptable.

Elite democracy is based on elitism, the rule by law, and the accountability by election. In Athens, Aristotle recognized that the rule by law required the separation of powers, including legislative branch to make the rule by law, the executive branch to enforce the rule by law, and the judicial branch where individual judges base their decisions solely on facts and law of individual cases independently of either the executive or legislative powers. This separation of powers for the rule by law served as a direct model of government for the writers of the American constitution. The Roman Republic (509-27 BC) combined both tyranny and democracy. The Republic was divided into the three basic parts including elected non-hereditary magistrates, a Senate to advise and consent, and popular assemblies. The Roman Republic served as a direct model of government for the writers of the American constitution.

The American Revolution led to the adoption of the United States Constitution in 1787. Only white, land owning men had the ability to vote in most states. As competitive democracy, the three branches, the legislative branch (the Senate and the House) to make the laws, the executive branch to enforce the laws, and the judicial branch to interpret the laws, compete against one another.

\subsubsection{Nationalist Democracy}

During the 18th century, the Age of Enlightenment centered on reason as the primary source of knowledge dominated the world of ideas in Europe. The ideas, such as nationalism, liberalism, and socialism of the Enlightenment undermined the authority of the monarchy and the Church, and paved the way for the political revolutions of the 18th and 19th centuries. At the same time, the Industrial Revolution in Europe changed the power structure of society and improved educational and living standard of people, especially the middle class people. The European population increased from 140 million in 1750 to 266 million in 
1850 due the improved living standard. As a result, through the improvement in education and living standard, the Industrial Revolution expanded elite democracy for few people to nationalist democracy based on nationalistic tradition for most people, liberal democracy based on liberty for all people, and socialist democracy based on equality for all people.

Nationalist democracy is a competitive democracy based on the combination of nationalism and democracy. Nationalism was derived from people's awareness of being part of a nation with common institutions, traditions, language, and customs. Nationalists owe their chief political loyalty to the nation rather than to a dynasty, city-state, or other political unit. Nationalism became a popular force for change by the French Revolution. Nationalism destroyed the old order of monarchies in Europe. The combination of nationalism and democracy established by the Industrial Revolution produced nationalist democracy. Nationalist democracy is based on tradition, the rule by law, and the accountability by election for most people. Nationalist democracy based on tradition excludes non-traditional people. The discrimination against non-traditional people and minorities are acceptable. In nationalist democracy, the power of tradition to compete in government belongs to majority people. People in traditional majority can compete in government.

Nationalist economy is the state-controlled economy to promote nationalism. The rapid changes in globalization and automation produce the problems of gross income inequality, serious job insecurity, and large scale immigration. The countries that cannot deal with such problems shift toward nationalist politics with nationalist economy which blames non-traditional groups and foreign countries for such problems. To prevent the competition from foreign countries, nationalist economy establishes protectionism that imposes tariffs, and restricts the movements of labor, goods, technology, and capital. With the restriction of competition, the economy under protectionism is inefficient. Nationalist economy also develops "military state capitalism" as military-industry complex [16] which is the joint venture between the state and the private owned enterprises where the state provides domestic and international markets by creating international tension and the private owned enterprises provide weapons to make profit. Military spending is not the best way to create jobs. A University of Massachusetts at Amherst study [17] found that \$1 billion in military spending created 8555 jobs. The same amount spent on public transit created 19,795 construction jobs. Spending on public works is the most cost-effective unemployment solution. Both protectionism and military state capitalism are wasteful.

\subsubsection{Liberal Democracy}

Liberal democracy is a competitive democracy based on the combination of liberalism and democracy. Liberalism based on Enlightenment principles held that people should have liberty as much as possible from government restraint. In the Age of Enlightenment, liberalism sought to liberate individuals from the authoritarian restrains of hereditary privilege, state religion, absolute monarchy, 
and the divine right of kings. Philosopher John Locke is often credited with founding liberalism based on the social contract which provides each person a natural right to life, liberty, and property. The Glorious Revolution of 1688, the American Revolution of 1776, and the French Revolution of 1789 used liberalism to justify the revolutions against authoritarian tyrannies.

In the Age of Enlightenment, liberalism was limited to few elite people. The combination of liberalism and democracy established by the Industrial Revolution produced liberal democracy with liberty for all people without discrimination. In liberal democracy, the power of the liberty to compete belongs to all people, and all people have liberty to compete. Liberal democracy is based on liberty, the rule of law, and the accountability of election. In the rule of law, all people, including people in power and people at the lowest level of citizenship, are all equal under the law itself. No one is above the law, and any law that is broken should be equally punished across the board, regardless of status in society or local community. The rule of law is carried out by the Aristotle's separation of powers.

According to the Democracy Index by the Economist Intelligence Unit (the world's leading resource for economic and business research) [18], in 2018, only 20 countries (4.5\% of the world population) are "full democracies", 55 (43.2\%) are "flawed democracies", 39 (16.7\%) are "hybrid regimes (illiberal democracy)", and $53(35.6 \%)$ are "authoritarian regimes". Full democracies are nations where civil liberties and basic political freedoms are not only respected, but also reinforced by a political culture conducive to the thriving of democratic principles. The top ten countries with full democracies are Norway, Iceland, Sweden, New Zealand, Denmark, Ireland, Canada, Finland, Australia, and Switzerland. In 2016, the United States was downgraded from a full democracy to a flawed democracy.

Liberal economy is the individual-controlled economy to promote liberty. Liberal economy involves free markets and private ownership of capital assets. Liberal economy opposes non-liberal economies, such as socialist economy, planned economy, and protectionism. The economic liberty is expressed in the laissez-faire doctrine in The Wealth of Nations (1776) by the Scottish economist and philosopher Adam Smith. According to Smith, competition in free trade benefits all parties, because competition leads to the production of more and better goods at lower prices. Any other arrangement, whether state control or monopoly, must lead to regimentation, exploitation, and economic stagnation. In market structure, Smith's competition is perfect competition where a large number of small firms without dominant firms compete against each other, and sell identical products such as stocks in stock market. In the market structure of monopolistic competition, a large number of small firms compete against each other, and sell differentiated similar products such as cereals. Each product is allowed to charge higher prices within a certain range. In the market structure of oligopoly, a small number of firms, such as telephone companies, compete 
against each other or collaborate with each other. They can use their collective market power to drive up prices and earn more profit. In the market structure of monopoly, the market is controlled by a single firm which often reduces output to increase prices and earn more profit. Liberal economy consists of all four types of market structures. As a result, a liberal state monitors and controls market structures to avoid excessively high prices.

\subsubsection{Socialist Democracy}

Socialist democracy is a competitive democracy based on the combination of socialism and democracy [19]. Henri de Saint-Simon (1760-1825) in France created the term "socialism" as a contrast to liberal individualism which failed to address poverty, social oppression, and gross inequalities in wealth social concerns during the Industrial Revolution in Europe. To achieve equality, he presented socialism as an alternative to liberal individualism based on the shared state ownership of resources. Different models of socialism have different degrees of state ownership and administration of the means of production and distribution of goods to produce different degrees of equality. The equality in socialist democracy includes at least the basic equality in healthcare, education, and basic income, and is not absolute equality in all aspects. Therefore, socialist democracy is still competitive other than basic equality. Socialist democracy is based on equality, the rule of law, and the accountability of election. For absolute equality, state has to own everything, and there is no private ownership for people. As a result, the political system for absolute equality is not democracy where power belongs to people. The political system for absolute equality is socialist statism instead of socialist democracy. In socialist democracy, the power of equal opportunity to compete belongs to all people, and all people have equal opportunity to compete.

Many countries, such as Norway, Iceland, Sweden, Denmark, Ireland, Finland, Germany, France, Brazil, and Peru have political parties promoting socialist democracy. The countries that have a socialist party that serves as a governing party are Armenia, Bolivia, Ecuador, Iceland, Nicaragua, Portugal, Serbia, Sweden, and Venezuela in 2019. Iceland and Sweden show that it is possible to have full democracy and socialist democracy at the same time.

Socialist economy in socialist democracy to promote economic equality includes substantial state intervention in the form of income redistribution and a welfare state. When income inequality is high, income redistribution such as progressive tax, negative income tax and inheritance tax is necessary to reduce inequality. The welfare state promotes equitable distribution of wealth, equal opportunity, and assistance to disable people. According to the Gini coefficient as the measurement of economic inequality, the countries that have low Gini coefficient to indicate high degree of equality are the European countries, such as Finland (the lowest Gini), Sweden, Norway, and Germany, with good income redistribution and welfare state. 


\subsubsection{Relationalist Democracy}

The power, rule, and accountability in relationalist democracy as in China, Russia, and Singapore are wellbeing, the rule of relation, and the accountability of professional qualification. In China, cooperative intergroup relation was expressed by Confucius (551-479BC) as harmony. "In practicing the rules of propriety, it is harmony that is prized." (Analects 1:12) Harmony is prized among the differences. Confucius said: "Noble persons seek harmony but not sameness. Petty persons seek sameness but not harmony." (Analects 13:23). Outwardly, harmony is maintained by the rule of relation as $l i$ to have appropriate manners that maintain the relations among different individuals, such as parent-child, siblings, spouses, and friends. In Confucian morality for kin group, parent-child relation involves care and teaching from parent and filial piety from child. Husband-wife and elder-younger siblings show respect, responsibility, and loyalty for each other. The Confucian morality for friends involves ren (benevolence), yi (uprightness), xin (faithfulness), shu (reciprocity), and li (propriety). To Legalism in China at the same period as Confucius, people were mostly competitors fighting against one another. The rational way to control such competition is fa (law). $L i$ in Confucianism is equivalent to $f a$ (law) in Legalism.

China adopted both $l i$ and $f a$, but $l i$ dominated fa. The rule by law had to be adjusted by the rule by relation. There was no competitive election system in China, because such partisan competition was considered as immoral in the cooperative society. As a result, there was no accountability by competitive election. The accountability of government was through professional qualification of government officials by the national examination system and the national promotion system. All princes had to be educated and trained to be professional rulers. Such Chinese professional qualification has been duplicated in competitive democracies as the bureaucrat-selection mechanism for civil service.

In 1978, Deng Xiaoping [20] started relationalist democracy by establishing the goal of moderately well-off society through reform and opening which involved cooperative rule of relation and accountability of professional qualification. (In terms of professional qualification, Deng Xiaoping famously said that it doesn't matter if a cat is black or white so long as it catches mice.) In relationalist democracy, all people cooperate to achieve wellbeing. Since 1978, mainland China has eradicated poverty at the rate of poverty reduction and at the number of poor people reduction unmatched anywhere and anytime in the world. Mainland China continues actively to industrialize and to eradicate poverty especially in the poor and remote rural areas as an important national goal.

Relationalist democracy is the most practical democracy which uses the best mixtures of methods to improve the wellbeing of people. As a result, it uses the mixture private owned enterprise (POE) and state owned enterprise (SOE). Much more people work for POE than SOE in China. It uses the mixture of election and professional qualification as described by Daniel A. Bell [21]. Relationalist democracy also uses experiments frequently to test new policies before the national implementations of new policies. 


\subsubsection{Mixed Democracy}

Each democracy has intergroup relation, maximum participation rates, and power. Each property has advantage and deficiency. For intergroup relation, the deficiencies for competitive and cooperative are chaos and corruption, respectively. For the maximum participation rates, the deficiencies for few/most and all are discrimination against other group and disloyalty to its own specific group, respectively. For power, the deficiencies for the absences of elitism/tradition, liberty, equality, and wellbeing are rootlessness, conformity, inequality, and impracticality, respectively. As a result, the deficiencies for elite democracy and nationalist democracy are chaos, discrimination, conformity, inequality, and impracticality. The deficiencies for liberal democracy are chaos, disloyalty, rootlessness, inequality, and impracticality. The deficiencies for socialist democracy are chaos, disloyalty, rootlessness, impracticality. The deficiencies for relationalist democracy are corruption, disloyalty, rootlessness, and inequality. The five types of democracy and their deficiencies are listed in Table 3.

In competitive democracies, such deficiencies allow different political parties with different competitive democracies to establish their bases to remedy such deficiencies. Typically, a competitive democratic country has far right conservative nationalistic political party for nationalist democracy to promote tradition and to remedy rootlessness, right-center conservative neoliberal political party for liberal democracy to promote liberty and to remedy conformity, and left progressive socialistic political party for socialist democracy to promote equality and to remedy inequality. Typically, upper income people favor liberal democracy, lower income people favor socialist democracy, and nationalist democracy is independent of income. A competitive democratic country has professional bureaucracy from relationalist democracy to provide stable wellbeing for their citizens to remedy impracticality. Therefore, as a whole, a functional and viable competitive democratic nation has competition, cooperation, tradition, liberty, equality, and wellbeing. In the same way, in cooperative democracy as relationalist democracy establish cooperatively all competitive democracies within the

Table 3. The five types of democracy and their deficiencies.

\begin{tabular}{lllll}
\hline democracy & $\begin{array}{l}\text { intergroup } \\
\text { relation }\end{array}$ & for & power & deficiencies \\
elite & competitive & few people elitism & $\begin{array}{l}\text { chaos, discrimination, conformity, inequality, } \\
\text { impracticality }\end{array}$ \\
nationalistic competitive & $\begin{array}{l}\text { most } \\
\text { people }\end{array}$ & tradition & $\begin{array}{l}\text { chaos, discrimination, conformity, inequality, } \\
\text { impracticality }\end{array}$ \\
liberal & competitive & all people & liberty & $\begin{array}{l}\text { chaos, disloyalty, rootlessness, inequality, } \\
\text { impracticality }\end{array}$ \\
socialistic & competitive & all people & equality & $\begin{array}{l}\text { chaos, disloyalty, rootlessness, conformity, } \\
\text { impracticality }\end{array}$ \\
well-off & cooperative & all people & wellbeing \\
corruption, disloyalty, rootlessness, conformity,
\end{tabular}


political system without opposition party. Therefore, as a whole, a functional and viable cooperative democratic nation has competition, cooperation, tradition, liberty, equality, and wellbeing.

Mixed democracy leads to mixed economy which blends planned economy with free market, and mixes state owned enterprise (SOE) with private owned enterprise (POE) [22]. In general, without enough capital and expertise in the private sector, developing countries use planned economy and SOE to start economy. With enough capital and expertise in the private sector, developed countries use free market and POE which are much more efficient than planned economy and SOE [23]. As a result, it is natural for a developing country to increase the portions of efficient free market and efficient POE as the economy becomes mature. However, nationalist economy reverses free market to planned economy as nationalist economy wants to develop national champions and protectionism to avoid the competitions from foreign firms. Therefore, nationalist economy is inefficient.

\section{International Relations}

International relations without clear boundary consist of competitive international relations and cooperative international relations. International relations as international intergroup relations reflect democracies as domestic intergroup politics. Liberal, socialist, and relationalist democracies are for all people, so they can generate cooperative international orders (liberal, socialist, and relationalist) for all nations within their respective democracies [3]. For example, liberal democracy can generate cooperative liberal international order for all liberal democratic nations. Elite democracy and nationalist democracy are not for all people, and are against foreigners, so they can only generate competitive international relation as competitive realism [4]. As a result, nationalism democracy results in realisms, while liberalism, socialism, and relationalism result in idealisms consisting of liberal international order, socialist international order, and relationalist international order.

\subsection{Realisms}

Realism as a school of thought in international relations theory believes that international relations ultimately are always and necessarily a field of conflict among competitive actors pursuing power. Realisms include defensive realism, offensive realism, and mutual destructive realism. In defensive realism, states think strategically about how to survive in the international system such as balance of powers. In balance of power, a nation or group of nations protect itself against another nation or group of nations by matching its power against the power of the other side. In Europe, balance of power was used from the end of the Napoleonic Wars to World War I. Prior to the 20th century, a number of separate and independent balance-of-power systems were in European, the American, and Asia. World War I culminated in the integration of most of the 
world's nations into a single balance-of-power system. During World War II, the fascist nations of Germany, Japan, and Italy were opposed by a global alliance of the Soviet Union, the United States, Britain, and China.

In offensive realism, states are rational actors, capable of coming up with sound strategies that maximize their prospects of survival to achieve hegemonic domination. Offensive realists believe that states behave more as power maximizers through maximizing offensive military power, while defensive realists believe that states behave more as security maximizers through balance of power.

The Cold War was a bipolar balance of power between the free-market states and the communist states. Nuclear weapons produce mutual destructive realism where nuclear weapons can destroy both sides in the conflict of hegemons who own nuclear weapons. The breakup of the Soviet Union in 1991 destroyed the Cold War's balance of power. Since both Russia and the United States retain their nuclear arsenals, the mutual destructive realism still exists. The result is military stalemate.

The global hegemonic conflicts lead to many disastrous proxy wars outside of hegemons. The global hegemonic conflicts can be avoided by the regional community defense realism through balance of regional powers. The establishment of the religious-geographic borders ended the religious war in the Thirty Years' War among Protestant and Catholic states. In the same way, the establishment of the cultural-geographic borders will end global hegemonic conflicts. As a result, the establishment of the rational territorial national-regional protective borders consisting of nations with geopolitical borders and the regional communities with cultural-geographic borders can avoid global conflicts. The regional communities exist in the "World Regional Community Organization" (the WRCO) where every country in the world belongs to a regional community [1]. The countries in one geographic region can find common identities to establish one regional community. The common identities of a regional community include some or all of the shared geography region, shared existing regional international organization, shared dominant cultural-religion, shard dominant language, shared dominant sociality, and shared dominant worldview. Each regional community has at least one economically strong country for its protection and strength. The 12 communities in the World Regional Community Organization (WRCO) are as follows and in Table 4.

The North American Community

Canada, Mexico, the USA

The South American Community

Antigua and Barbuda, Argentina, Bahamas, Barbados, Belize, Bolivia, Brazil, Chile, Colombia, Costa Rica, Cuba, Dominica, Dominican Republic, Ecuador, El Salvador, Grenada, Guatemala, Guyana, Haiti, Honduras, Jamaica, Nicaragua, Panama, Paraguay, Peru, St. Kitts and Nevis, St. Lucia, St. Vincent and The Grenadines, Suriname, Trinidad and Tobago, Uruguay, Venezuela. 
Table 4. The World Regional Community Organization (WRCO).

\begin{tabular}{|c|c|c|c|c|}
\hline $\begin{array}{l}\text { regional } \\
\text { community }\end{array}$ & $\begin{array}{l}\text { major } \\
\text { country }\end{array}$ & $\begin{array}{l}\text { major existing } \\
\text { organization }\end{array}$ & $\begin{array}{l}\text { major } \\
\text { cultural-religious } \\
\text { influence }\end{array}$ & $\begin{array}{l}\text { major } \\
\text { languages }\end{array}$ \\
\hline North American & USA & NAFTA & Christianity & English-Spanish \\
\hline South American & Brazil & OAS & Christianity & Spanish-Portuguese \\
\hline East Asian & China & & Confucianism & mixed languages \\
\hline South Asian & India & ASEAN & Indian culture & mixed language \\
\hline Midwest Asian & Turkey & & Islam & mixed language \\
\hline Southwest Asian & $\begin{array}{l}\text { Saudi } \\
\text { Arabia }\end{array}$ & Arab League & Islam & Arabic \\
\hline Eurasian & Russia & EAEU & Christianity-Islam & Russian \\
\hline West European & Germany & EU & Christianity & mixed language \\
\hline North African & Egypt & Arab League, ECOWAS & Islam & mixed language \\
\hline West African & Nigeria & ECOWAS and ECCAS & Christianity & mixed language \\
\hline $\begin{array}{l}\text { East-South } \\
\text { African }\end{array}$ & $\begin{array}{l}\text { South } \\
\text { Africa }\end{array}$ & $\begin{array}{l}\text { COMESA, EAC, and } \\
\text { SADC }\end{array}$ & Christianity & mixed language \\
\hline $\begin{array}{l}\text { Pacific Islands } \\
\text { Forum }\end{array}$ & Australia & $\begin{array}{l}\text { Pacific Islands Forum } \\
\text { Community }\end{array}$ & Christianity & English \\
\hline
\end{tabular}

\section{The East Asian Community}

China, Japan, Mongolia, Philippines, the Republic of Korea, the Democratic People's Republic of Korea, Viet Nam

The South Asian Community

Bangladesh, Bhutan, Brunei, Cambodia, Laos, Malaysia, Singapore, India, Indonesia, Maldives, Myanmar, Nepal, Sri Lanka, Thailand, Timor-Leste

The Midwest Asian Community

Afghanistan, Iran, Iraq, Pakistan, Syria, Turkey

The Southwest Asian Community

Bahrain, Israel, Jordan, Lebanon, Kuwait, Oman, Palestine, Qatar, Saudi Arabia, the United Arab Emirates, Qatar, Yemen

The Eurasian Community

Armenia, Azerbaijan, Belarus, Georgia, Kazakhstan, Kyrgyzstan, Russia, Tajikistan, Turkmenistan, Uzbekistan

\section{The West European Community}

Albania, Andorra. Austria. Belgium. Bosnia and Herzegovina, Bulgaria. Croatia. Cyprus. Czech Republic, Denmark, Estonia, Finland, France, Germany, Greece, Hungary, Iceland, Ireland, Italy, Kosovo, Latvia, Liechtenstein, Lithuania, Luxembourg, Macedonia, Malta, Moldova, Monaco, Montenegro, Netherlands, Norway, Poland, Portugal, Romania, San Marino, Serbia, Slovakia, Slovenia, Spain, Sweden, Switzerland, Ukraine, the United Kingdom, Vatican City

The North African Community

Algeria, Comoros, Burkina Faso, Djibouti, Egypt, Gambia, Guinea, Gui- 
nea-Bissau, Libya, Mali, Mauritania, Morocco, Niger, Senegal, Sierra Leone, Somalia, Sudan, Tunisia, Western Sahara

The West African Community

Benin, Cape Verde, Cameroon, Central African Republic, Chad, Côte d'Ivoire, Democratic Republic of the Congo, Equatorial Guinea, Gabon, Ghana, Liberia, Nigeria, Republic of the Congo, São Tomé and Príncipe, Togo

The East-South African Community

Angola, Botswana, Burundi, Eritrea, Ethiopia, Kenya, Lesotho. Madagascar, Malawi. Mauritius, Mozambique, Namibia, Rwanda, Seychelles, South Africa, South Sudan, Swaziland, Tanzania, Uganda, Zambia, Zimbabwe

Pacific Islands Forum Community

Australia, Fiji, Kiribati, Marshall Islands, Micronesia, Nauru, New Zealand, Palau, Papua New Guinea, Samoa, Solomon Islands, Tonga, Tuvalu, Vanuatu

With the territorial regional protective border, each regional community enforces the "Monroe Doctrine" that forbids military intrusion from the countries outside of a regional community except the intervention approved by the United Nations. As a result, all overseas military bases as the military intrusion from the countries outside of a regional community have to be abolished. All defense treaties connected to the countries outside of a regional community also have to be ended. The regional communities which are for military defense allow individual nations to maintain all international economic treaties inside and outside of the communities. Different regional communities will have different degrees of economic cooperation within the communities.

\subsection{Liberal International Order}

After the World War II, The United Nations (UN) formally created in October 1945 was established as a world government that would maintain international order, but many forces that worked against such an outcome included the division of the world into two large political blocs identified with the North Atlantic Treaty Organization (NATO) and the Warsaw Pact. These two large military and political blocs not only confronted one another directly, they also established two opposing international orders to compete globally for support from the so-called Third World nations of Asia and Africa. Within an international order, cooperative idealism replaced competitive realism among nations, so the nations maintained peace and cooperation within the international order.

Liberal international order establishes multilateral rule-based liberty in politics and economy in terms of liberal democracy and internal and international free market. Liberal international order promotes and assists liberal democratic movements in other countries, and prevents socialistic international order expansion. Liberal international economic order established the World Trade Organization to create and implement free trade agreements, the World Bank to provide aid to developing countries, and the International Monetary Fund to foster global monetary cooperation, secure financial stability, facilitate interna- 
tional trade, promote high employment and sustainable economic growth, and reduce poverty around the world. Liberal international economic order has contributed the global economic growth.

During the Cold War, liberal international order led by the USA was useful to counter socialist international order led by the USSR for balance of power, so the West strongly adhered to liberal international order. Liberal international order won the Cold War, and lost its usefulness. Without threat from socialist international order, liberal international order is threatened by developments within the West itself [24]. Liberal international order has created economic inequality in the West. In the countries that have serious economic inequality and large-scale immigration, liberal democracy itself appears fragile and polarized, vulnerable to far right populism as nationalism. The centrist and progressive coalitions that support liberal international order have weakened. The highly interdependent global economy cannot function well with nationalistic protectionism.

\subsection{Socialist International Order}

One of the major international organizations for socialist democracy is the Socialist International whose origins go back to the early international organizations of the labor movement, has existed in its present form since 1951, when it was re-established at the Frankfurt Congress. It currently brings together 147 socialist democratic parties and organizations from all continents. The goals of the Socialist International are freedom for competitive democracy, equality, and solidarity. Socialist struggles in the original capitalist nations made gains in equality, which in turn made the extension of competitive democracy possible in individual countries without turning into chaos. The Socialist International continues assist socialist democratic parties globally. The Socialist International also involves environmental international order based on equality between human impact and environment. Environmental international order produced the Paris Agreement to protect global environment. Environmental international order is strong in Europe.

During the Cold War, socialist international order for classless state led by the USSR promoted classless state, equality, and solidarity. During most of the Cold War, the USSR as the World's second largest economy behind the USA supported socialistic international order. By the 1980s, the world socialist economic system embraced one-third of the world's population with less than 15 percent of global economic output. The economic international order was the Council for Mutual Economic Assistance (Comecon) that that comprised the countries of the Eastern Bloc and other communist states to resist liberal economic international order [25]. Since the late 1970s, the long and costly war in Afghanistan, the high military expenditure, and the failure to produce consumer products effectively and to develop information technology adequately by the planned economy caused the economy falling behind [26]. Eventually, the socialistic international order led by the USSR lost the Cold War. 


\subsection{Relationalist International Order}

Liberal international order espousals global liberty, socialist international order promotes global equality, and relationalist international order supports global wellbeing. The basic assumption of relationalist international order is that no nation stands alone, and all nations are related to one another in the community of common destiny that produces wellbeing as the state of being comfortable, healthy, secure, and happy. The Western international orders in their Western perception view each nation separately to compete for liberty and equality without relations in the community of common destiny. As a result, from the Eastern perception, relationalist international order complements liberal international order and socialist international order.

One way to implement relationalist international order is through infrastructural international order to connect various countries and regions such as the Road Belt Initiative (BRI) proposed by Xi Jinping in September and October 2013 during visits to Kazakhstan and Indonesia [27]. It involves infrastructure development and investments in 152 countries and international organizations in Asia, Europe, Africa, the Middle East, and the Americas. The origin of the BRI is The Silk Road started by China's Han Dynasty (206 BC - 220 AD), which forged trade networks throughout what are today the Central Asian countries, Indi, Pakistan, and Europe. Use of the route peaked during the first millennium, under the leadership of first the Roman and then Byzantine Empires, and the Tang Dynasty (618 - 907AD) in China. The BRI involves the overland Silk Road Economic Belt and the Maritime Silk Road. The BRI also plans to build fifty special economic zones to launch economic developments quickly. The BRI helps the economic developments in developing countries. With adequate wellbeing in all nations, the large scale migration of people from poor nations to rich nations can be minimized. Morgan Stanley has predicted China's overall expenses over the life of the BRI could reach $\$ 1.2$ - 1.3 trillion by 2027. In comparison, America has spent \$5.9 trillion on wars in the Middle East and Asia since 2001.

\subsection{Mixed International Relation}

The world peace and prosperity can be maintained by the mixed international relation consisting of the regional community defense realism, liberal economic international order, socialist economic-environmental international order, relationalist infrastructural international order, and the United Nations as the platform of all nations. The regional community defense realism minimizes global hegemonic conflicts and proxy wars. Liberal economic international order enhances global economic growth. Socialist economic-environmental international order protects human welfare and environment for the present and future humans. Relationalist infrastructural international order produces the community of common destiny, enhances international trade, and minimizes the large scale migration of people from poor nations to rich nations. The United Nations is the platform for all nations to resolve international problems. France, the USA, Germany, and China are the strong proponents of the regional community de- 
fense realism, liberal economic international order, socialist economic-environmental international order, and relationalist infrastructural international order, respectively.

\section{Summary}

This paper proposes the five different democracies and their international relations. Democracy literally means that power belongs to the common people instead of dictators and inherited kings-queens, and inherited aristocrats. Different types of powers and different types of the common people constitute different types of democracies. Within a democratic nation, the intergroup relation among different social groups can be competitive or cooperative. Power is implemented by the state which is regulated by the rule and the accountability. As a result, this paper proposes that democracies are derived from the maximum participation rates (few, most, and all) of people in government, intergroup relations (competitive and cooperative) within a country, the powers (elitism, tradition, liberty, equality, and wellbeing), the rules (the rule by/of law and the rule of relation), and the accountabilities (the accountability by/of election and the accountability of professional qualification).

The five democracies are elite democracy, nationalist democracy, liberal democracy, socialist democracy, and relationalist democracy. 1) Elite democracy for few elite people is based on competition, elitism, the rule by law, and the accountability by election. The power of elitism to compete in government belongs to few people. Few elite people can compete in government. 2) Nationalist democracy for most people is based on competition, tradition, the rule by law, and the accountability by election. The power of tradition to compete in government belongs to majority people. People in traditional majority can compete in government. 3) Liberal democracy for all people is based on competition, liberty, the rule of law, and the accountability of election. The power of the liberty to compete belongs to all people. All people have liberty to compete. 4) Socialist democracy for all people is based on competition, equality, the rule of law, and the accountability of election. The power of equal opportunity to compete belongs to all people. All people have equal opportunity to compete. 5) Relationalist democracy for all people is based on cooperation, wellbeing, the rule of relation, and the accountability of professional qualification. The power of wellbeing from cooperation belongs to all people. All people cooperate to achieve wellbeing.

Different people in different times, cultures, and political situations have different democracies. The competitive democracies originated from the West have competitive intergroup relation, and include elite, nationalist, liberal, and socialist democracies. The cooperative democracy originated from the East has cooperative intergroup relation, and includes relationalist democracy. Each democracy has advantages and deficiencies. The democracies today are mostly mixed democracies to minimize deficiencies. The optimal mixed democracies have competition, cooperation, tradition, liberty, equality, and wellbeing. 
Table 5. The five democracies and international relations.

\begin{tabular}{|c|c|c|c|c|c|}
\hline democracy & for & $\begin{array}{l}\text { intergroup } \\
\text { relation }\end{array}$ & power & rule and accountability & $\begin{array}{l}\text { international } \\
\text { relation }\end{array}$ \\
\hline $\begin{array}{l}\text { elite } \\
\text { democracy }\end{array}$ & $\begin{array}{l}\text { few } \\
\text { people }\end{array}$ & competitive & elitism & $\begin{array}{l}\text { rule by law, accountability } \\
\text { by election }\end{array}$ & realism \\
\hline $\begin{array}{l}\text { nationalist } \\
\text { democracy }\end{array}$ & $\begin{array}{l}\text { most } \\
\text { people }\end{array}$ & competitive & tradition & $\begin{array}{l}\text { rule by law, accountability } \\
\text { by election }\end{array}$ & realism \\
\hline $\begin{array}{l}\text { liberal } \\
\text { democracy }\end{array}$ & $\begin{array}{l}\text { all } \\
\text { people }\end{array}$ & competitive & liberty & $\begin{array}{l}\text { rule of law, accountability } \\
\text { of election }\end{array}$ & $\begin{array}{l}\text { liberal } \\
\text { international } \\
\text { order }\end{array}$ \\
\hline $\begin{array}{l}\text { socialist } \\
\text { democracy }\end{array}$ & $\begin{array}{l}\text { all } \\
\text { people }\end{array}$ & competitive & equality & $\begin{array}{l}\text { rule of law, accountability } \\
\text { of equality }\end{array}$ & $\begin{array}{l}\text { socialist } \\
\text { international } \\
\text { order }\end{array}$ \\
\hline $\begin{array}{l}\text { relationalist } \\
\text { democracy }\end{array}$ & $\begin{array}{l}\text { all } \\
\text { people }\end{array}$ & cooperative & wellbeing & $\begin{array}{l}\text { rule of relation, } \\
\text { accountability of } \\
\text { professional qualification }\end{array}$ & $\begin{array}{l}\text { relationalist } \\
\text { international } \\
\text { order }\end{array}$ \\
\hline
\end{tabular}

International relations as international intergroup relations reflect democracies as domestic intergroup politics. Elite/nationalist democracies for few/most people lead to the competitive international relation of realisms. Liberal, socialist, and relationalist democracies for all people lead to the cooperative international relations of liberal, socialist, and relationalist international orders, respectively for all nations within their respective international orders. For example, liberal democracy can generate cooperative liberal international order for all liberal democratic nations. The five democracies and international relations are listed in Table 5.

Peace and prosperity in the world can be maintained by the regional community defense realism against global hegemonic conflicts and proxy wars, liberal economic international order to promote economic growth, socialist economic-environmental international order to protect human welfare and environment, and relationalist infrastructural international order to produce the community of common destiny, to enhance international trade, and to minimize the large scale migration of people from poor nations to rich nations.

\section{Conflicts of Interest}

The author declares no conflicts of interest regarding the publication of this paper.

\section{References}

[1] Chung, D. (2018) Evolutionary Origin of Politics and Political Evolution: Neuropolitics. Journal of Behavioral and Brain Science, 8, 538-561. https://doi.org/10.4236/jbbs.2018.810033

[2] Schumpeter, J. (1942) Capitalism, Socialism, and Democracy. George Allen \& Unwin, London.

[3] Crawford, R. (2005) Idealism and Realism in International Relations. Routledge, Abingdon-on-Thames. 
[4] Mearsheimer, J. (2001) The Tragedy of Great Power Politics. W.W. Norton \& Company, New York.

[5] Turner, J.C. and Reynolds, K.J. (2010) The Story of Social Identity. In: Postmes, T. and Branscombe, N., Eds., Rediscovering Social Identity: Core Sources, Psychology Press, New York, 13-32.

[6] Cohen, T., Montoya, R. and Insko, C. (2006) Group Morality and Intergroup Relations: Cross-Cultural and Experimental Evidence. Personality and Social Psychology Bulletin, 32, 1559-1572. https://doi.org/10.1177/0146167206291673

[7] Hamlin, J., Mahajan, N. and Wynn, K. (2013) Not Like Me = Bad Infants Prefer Those Who Harm Dissimilar Others. Psychological Science, 24, 589-594. https://doi.org/10.1177/0956797612457785

[8] Emirbayer, M. (1997) Manifesto for a Relational Sociology. The American Journal of Sociology, 103, 281-317. https://doi.org/10.1086/231209

[9] Nisbett, R. (2004) The Geography of Thought: How Asians and Westerners Think Differently ... and Why. Free Press, New York.

[10] Yuki, M., et al. (2005) Cross-Cultural Differences in Relationship- and Group-Based Trust. Personality and Social Psychology Bulletin, 31, 48-62. https://doi.org/10.1177/0146167204271305

[11] Grossmann, I. and Kross, E. (2010) The Impact of Culture on Adaptive versus Maladaptive Self-Reflection. Psychological Science, 21, 1150-1157.

https://doi.org/10.1177/0956797610376655 http://pss.sagepub.com/content/early/2010/07/12/0956797610376655

[12] Shapiro, I. (2017) Collusion in Restraint of Democracy: Against Political Deliberation. Dædalus, 146, 77-84. https://doi.org/10.1162/DAED_a_00448

[13] Fukuyama, F. (2011) Origins of Political Order: From Prehuman Times to the French Revolution. Farrar, Straus and Giroux, New York.

[14] Francis, F. (2014) Political Order and Political Decay: From the Industrial Revolution to the Globalization of Democracy. Farrar, Strauss, and Giroux, New York.

[15] Chung, D. (2019) The Mental Origins and the Evolution of Political Order. Journal of Behavioral and Brain Science, 9, 211-245. https://doi.org/10.4236/jbbs.2019.96018

[16] Ledbetter, J. (2011) 50 Years of the Military-Industrial Complex. New York Times, January 25.

[17] Pollin, R. and Garrett-Peltier, H. (2011) The U.S. Employment Effects of Military and Domestic Spending Priorities: 2011 Update. Political Economy Research Institute, the University of Massachusetts, Amherst.

[18] The Economist Intelligence Unit (2019) Democracy Index 2018: Me Too? https://www.eiu.com/Handlers/WhitepaperHandler.ashx?fi=Democracy_Index_201 8.pdf\&mode $=$ wp\&campaignid $=$ Democracy 2018

[19] Busky, D. (2000) Democratic Socialism: A Global Survey. Praeger, Santa Barbara.

[20] Vogel, E. (2011) Deng Xiaoping and the Transformation of China. The Belknap Press of Harvard University Press, Cambridge.

[21] Bell, D. (2015) The China Model: Political Meritocracy and the Limits of Democracy. Princeton University Press, Princeton. https://doi.org/10.1515/9781400865505

[22] Schiller, B. (2010) The Micro Economy Today. McGraw-Hill/Irwin, New York.

[23] Goldeng, E., Grünfeld, L. and Benito, G. (2008) The Performance Differential between Private and State Owned Enterprises: The Roles of Ownership, Management 
and Market Structure. Journal of Management Studies, 45, 1244-1273. https://doi.org/10.1111/j.1467-6486.2008.00790.x

[24] Ikenberry, G. (2018) The End of Liberal International Order? International Affairs, 94, 7-23. https://doi.org/10.1093/ia/iix241

[25] Kaser, M. (1967) Comecon: Integration Problems of the Planned Economies. Oxford University Press, Oxford.

[26] Gaidar, Y. (2007) Collapse of an Empire: Lessons for Modern Russia. Brookings Institution Press, Washington DC.

[27] Kuo, L. and Kommenda, N. (2018) What Is China's Belt and Road Initiative? The Guardian, 5 September 2018, London. 